AperTO - Archivio Istituzionale Open Access dell'Università di Torino

\title{
Pain in amyotrophic lateral sclerosis
}

\section{This is the author's manuscript}

Original Citation:

Availability:

This version is available http://hdl.handle.net/2318/1636247

since 2017-05-19T07:32:01Z

Published version:

DOI:10.1016/S1474-4422(16)30358-1

Terms of use:

Open Access

Anyone can freely access the full text of works made available as "Open Access". Works made available under a Creative Commons license can be used according to the terms and conditions of said license. Use of all other works requires consent of the right holder (author or publisher) if not exempted from copyright protection by the applicable law. 


\section{Pain in amyotrophic lateral sclerosis}

Adriano Chiò, $M D^{1}$ Gabriele Mora, $M^{2}$ Giuseppe Lauria, $M^{3}$

${ }^{1}$ ALS Centre, "Rita Levi Montalcini" Department of Neuroscience, University of Turin, Italy;

${ }^{2}$ Neurorehabilitation Department, IRCCS Salvatore Maugeri Foundation, Institute of Milan, Milan, Italy;

${ }^{3}$ Neuroalgology Unit and Motor Neuron Diseases Centre, IRCCS “Carlo Besta” Neurological Institute, Milan, Italy.

Correspondence to:Prof. Adriano Chiò, ALS Centre, "Rita Levi Montalcini" Department of Neuroscience, University of Turin, via Cherasco 15, 10126 Torino. Email: achio@usa.net 


\begin{abstract}
Pain is a largely neglected symptom in amyotrophic lateral sclerosis (ALS) although reported in a majority of patients. It occurs at all stages of the disease and can be an onset symptom preceding motor dysfunction. Pain is correlated with a deterioration of the patient's quality of life and increased depression. In the later stages of ALS, the pain severity can be such as to require increasing use of sedative-analgesic drugs and is among the events predicting clinical deterioration and death. The site of pain depends on the pain type or underlying mechanism, i.e. painful cramps (lower limbs, hands), nociceptive pain (shoulders, joints, pressure sores) or neuropathic pain (feet, lower limbs). Given the multifactorial nature of pain in ALS, different treatments have been suggested, ranging from non-steroidal anti-inflammatory agents, drugs for neuropathic pain, opioids and, most recently, cannabinoids, to physical therapy strategies and preventive assistive devices. Further understanding of the pathophysiology is crucial to drive assessment in clinical trials of therapeutic strategies targeted at specific mechanisms and studies of individually tailored therapies.
\end{abstract}




\section{Introduction}

Amyotrophic lateral sclerosis (ALS) is a rare neurodegenerative disease whose outcome is fatal within 2-4 years from onset. ${ }^{1}$ The ALS degenerative process involves upper and lower motor neurons with onset usually at the bulbar or spinal levels, causing progressive loss of strength at limbs, dysphagia, dysarthria and respiratory failure. Motor neuron degeneration is the predominant cause of patient disability throughout all ALS stages and is eventually responsible for death. However, many patients also have involvement of extra-motor components, in particular the prefrontal cortex, associated with cognitive impairment or frontotemporal dementia, ${ }^{2,3}$ and although central nervous system sensory structures are generally spared, some evidence for sensory system involvement comes from neuropathological, ${ }^{4,5}$ imaging, $^{6,7}$ and clinical ${ }^{5,8,9}$ studies, as well as from rodent models of ALS. ${ }^{10,11}$

Pain was quite a neglected symptom in ALS up until about ten years ago ${ }^{12}$ owing to a misconception of the disease as purely of a motor nature, that leads clinicians not to ask their patients about pain, ${ }^{12,13}$ as also has been the case with other non-motor symptoms. However, in the last decade, the variability of ALS between affected individuals has clearly emerged, and among the wide spectrum of neurological defects and adjunctive manifestations that have been investigated, several studies have focused on pain in $\mathrm{ALS}^{13-18}{ }^{18}$ confirming earlier observations. ${ }^{19-21}$ Furthermore, pain has been considered, mostly from a therapeutic point of view, in the main guidelines of ALS treatment, ${ }^{22,23}$ being also the subject of a Cochrane review. ${ }^{24}$ Nevertheless, the incidence, severity, distribution, underlying mechanisms and treatment of pain in ALS have not been completely addressed, mainly due to the lack of a standardized method for diagnosing pain, the relative lack of data regarding pain determinants, and confounding variables.

The importance of identifying and assessing pain in ALS patients cannot be overlooked. Pain has profound detrimental effects on ALS patients' and caregivers' quality of life ${ }^{14,18,25}$ and there are initial indications that it may have prognostic significance. ${ }^{26,27}$ Different types of pain might arise from different underlying mechanisms - e.g., primary causes of pain such as neuropathic pain could arise from the impairment of the somatosensory pathways, whereas secondary causes of pain, due to the effects of tissue damages, are mainly nociceptive - and understanding the pathophysiology of pain in ALS would be relevant to determine the best treatments for individual patients. 
In this review, we summarise current understanding of pain in ALS and explore potential directions for future research. We first briefly describe the epidemiology of pain in ALS, before outlining the key clinical characteristics, including the relation between pain and other comorbidities. We then discuss potential underlying mechanisms, with assessment of the evidence for neuropathic, nociceptive, and central sensitisation origins of pain in this disease. Genetic correlates of pain are discussed and, finally, we review current management strategies and emphasise the need for more rigorous studies of treatments for pain in ALS.

\section{Epidemiology of pain in ALS}

There are few systematic studies on pain in ALS and only three longitudinal studies (Supplementary Table 1). The reported frequency of pain in ALS varies greatly, from less than $15 \%{ }^{20,28,29}$ up to $85 \% .{ }^{14,17,25,30-33}$ This large variability is related to the different study designs and settings, and the different instruments used to identify and measure pain. Moreover, the number of ALS patients included in these studies is rather small, ranging from $7^{33}$ to $424 .{ }^{17}$ Interestingly, larger observational studies on the natural history of ALS do not even mention pain among the clinical features of the disease. ${ }^{34,35}$ It suggests that the investigational setting, as well as the definition of pain, the tools used and, likely, the attention that neurologists and ALS patients pay to pain may all have a significant impact on the determination of its epidemiology, resulting in quite opposite conclusions. For instance, two studies, one randomized clinical trial ${ }^{18}$ and one study focused on coping, ${ }^{36}$ both indicated that loss of strength, ability to move and fatigue, but not pain, were perceived as the most significant non-bulbar symptoms. In net contrast to this, studies focusing on pain reported it as one of the most significant causes of suffering among ALS patients, ${ }^{14,21}$ also as compared with other neuromuscular diseases. ${ }^{32}$ Finally, it should be considered that cognitive impairment limits the reliability of pain assessment and, therefore, the interpretation of epidemiological studies.

\section{Assessment of pain in the clinical setting}

Despite the high frequency of pain in ALS and its negative impact on patients' quality of life, both the Practice Parameters of the American Academy of Neurology ${ }^{22}$ and the European Guidelines on the Clinical Management of $\mathrm{ALS}^{23}$ discuss its treatment in ALS but do not suggest a proactive screening of this symptom during the course of the disease. In an online survey on pain in USA, in which only one-third of physicians from ALS clinics responded, ${ }^{37} 92 \%$ stated that pain was routinely assessed in all practices, not only by the caring neurologist but also by other team 
members like nurses and physical and occupational therapists. Pain was usually assessed by openended questions. Less than $20 \%$ of ALS clinics used rating scales or questionnaires to assess pain. Almost $65 \%$ of physicians reported the need for better pain management practices and more than one-third emphasized the need for better training. This indicates that there is a sufficient awareness on the issue of pain among ALS multidisciplinary teams, but also that pain is frequently not dealt with standard protocols and adequate training.

In studies that have formally assessed pain in patients with ALS, the most frequently used measure has been the Brief Pain Inventory questionnaire, ${ }^{14,17,25,30,32}$ a self-report tool that rates current pain, its intensity over the previous week and the interference with mood, physical, working and social activity, and sleep. Further tools such as the Neuropathic Pain Scale, the short-form McGill Pain Questionnaire, the Neuropathic Pain Symptom Inventory, the Neuropathic Pain Diagnostic Questionnaire and other questionnaires were used in other studies. ${ }^{28,31}$ These questionnaires are validated and can be used as discriminative and descriptive instruments to screen patients, though their ability in diagnosing the different forms of pain in individual patients is arguable. ${ }^{38}$

Moreover, pain perception is known to be strongly affected by attention, hypervigilance and context, ${ }^{39}$ all of which can variably influence the experience of pain and, therefore, how pain is recorded and to what degree it interferes with life.

\section{Characteristics of pain in ALS and relation to comorbidities}

In patients with ALS, there is great variability in the clinical manifestations and localisation of pain (Figure 1), which depend on whether the pain represents primary mechanisms or results from the secondary effects of motor degeneration (see below for discussion of mechanisms). Pain severity and the presence and nature of pain over the disease course also vary between individuals, and in some cases pain is evident before the presence of motor symptoms. Pain can be acute or chronic (when continuous for at least 3 months or longer) in ALS. In case-control studies, pain has been reported to be significantly more frequent in ALS patients than in healthy and neurological ageand sex-matched controls, ${ }^{14,25,30}$ indicating that pain in ALS is not merely related to comorbid disorders; nevertheless, assessment of comorbid disorders is crucial for the accurate interpretation of pain assessments in these patients. Genetic factors are known to influence pain onset and course, as well as individual response to analgesics. The role of ALS causative genes like SOD1 and C9orf72, as well as that of pain-related genes like sodium channels in influencing in ALS 
has not been investigated and is still little known. This issue is discussed in the supplementary file 1.

\section{Types of pain}

Primary causes of pain in ALS include pain with neuropathic features such as spontaneous (e.g. burning, tingling, paroxysmal shooting pain) and evoked (e.g. allodynia, hyperalgia, aftersensation) symptoms, and can affect distal extremities and can be focal or diffuse. However, two clinical studies on neuropathic pain in ALS provide no or only weak evidence for this pain type in patients with ALS: in a case-control study, no patients scored high enough in the Pain Detect Questionnaire to reach the neuropathic threshold, and $80 \%$ of ALS patients scored less than 12/38, suggesting that their pain was nociceptive in nature, ${ }^{25}$ while a cross-sectional study showed that only $9 \%$ of 96 patients with pain had features of neuropathic pain according to the Neuropathic Pain Diagnostic Questionnaire and higher pain intensity score. ${ }^{40}$ Spasticity and cramps are other common primary causes of pain in ALS. Cramps are the major cause of pain in about one-quarter of patients, mainly with the spinal form. ${ }^{41}$ They originate from instability of motor units at the level of distal motor nerves as demonstrated by needle electromyography studies and are typically associated with muscle denervation. ${ }^{42}$

The above-mentioned case-control study ${ }^{25}$ reported itch among non-motor symptoms in about $35 \%$ of ALS patients, but it did not provide data on possible correlation with opioid therapy that was followed by $29 \%$ of patients, making unclear the relationship with ALS. Indeed itch, besides occurring in a wide range of systemic, dermatological and neurological illnesses, ${ }^{43,44}$ can be a side effect of drugs like opioids and chloroquine. ${ }^{45}$

Secondary (mainly nociceptive) causes of ALS pain develop as disease progresses, whereby atrophy and weakness of muscles and prolonged immobility cause degenerative changes in connective tissue, bones and joints leading to musculoskeletal pain. Joint contractures are common and ALS patients frequently experience shoulder pain due to loss of strength of the periscapular muscles. ${ }^{46}$ Skin pressure can cause decubitus ulcers, though these are rather uncommon despite the poor mobility. Some patients also complain of diffuse and unexplained pain, mainly in the late phase of the disease.

Non-invasive ventilation (NIV) is another cause of secondary pain or discomfort due to interfacerelated problems with the mask. Skin lesions, particularly ulcers on the nasal bridge, are painful 
complications and common reasons for poor adaptation or NIV failure. In a study on 37 ALS patients on invasive ventilation, ${ }^{47}$ more than $80 \%$ of patients reported to suffer from pain due to remaining in the same physical position for prolonged periods of time; $70 \%$ referred that the ventilator hose weighing or pulling on the throat caused severe pain, and $50 \%$ reported the experience of pain associated with suctioning of saliva or phlegm. The latter two causes of pain are of particular interest because often overlooked by caregivers and physicians.

Moreover, a recent study in ALS suggested that mechanical ventilation, while corrects hypoventilation and alleviates dyspnoea, might increase the susceptibility to pain in terms of reduced pain pressure threshold. ${ }^{48}$ Dyspnoea is known to activate the diffuse nociceptive inhibitory control as demonstrated by its inhibitory effect on painful stimuli (e.g. laser evoked potentials) ${ }^{49}$ and nociceptive spinal flexion reflex (e.g. nociceptive RIII reflex). ${ }^{50}$ Although preliminary and not yet supported by focused clinical studies, these data ${ }^{48}$ suggest that a careful assessment of pain may be warranted in ALS patients after starting the mechanical ventilation.

\section{Localisation of pain}

Studies including the assessment of pain distribution in ALS did not reveal a specific localization of symptoms, which could involve distal and proximal sites of upper and lower extremities and the back $^{14,15,17,25,30,31}$ or be widespread. ${ }^{32}$ Conversely, studies investigating small nerve fibre loss reported cases of painful symptoms predominantly in the feet, ${ }^{28,29}$ suggesting that pain recording in ALS may be biased by the study design. However, almost all studies agreed that pain is less common in the bulbar form of ALS. ${ }^{14,15,41}$ implying that skeletal muscle involvement may be an important risk factor.

\section{Severity of pain}

Pain intensity was recorded as mild (e.g. $\leq 3$ on a $0-10$ rating score) in most studies, ${ }^{14,17,25,30}$ but in other studies patients reported higher scores - from moderate ${ }^{32}$ to severe or unbearable pain. ${ }^{31}$ In keeping with these findings, one study demonstrated that pain intensity did not correlate with the Pain Interference Score ${ }^{17}$ suggesting that pain itself, but not its severity, may be a major determinant of suffering in ALS patients. However, more than $50 \%$ of ALS patients complaining of pain were reported to use pain drugs ${ }^{14,17,25,30,40,46}$ more frequently than population-based controls, indicating that when pain is detected in ALS patients is more likely to be actively treated than in the general population. ${ }^{14}$ 
It has been reported that pain may anticipate motor impairment by two or more years, although a direct causality has not been convincingly proven. ${ }^{20,51}$ Painful cramps in the legs and hands are often present at the onset of disease (Panel 1). ${ }^{52}$ Similarly, shoulder pain has been reported as the presentation symptom in about $10 \%$ of ALS patients, often associated with proximal upper limb weakness, but not with age, gender, manual labour, prior shoulder problems, ALS phenotype, or initial region of involvement. ${ }^{46}$ In a case-control study, ${ }^{25} 25 \%$ of ALS patients complaining of pain had pain before the onset of disease. In the largest survey on this topic, ${ }^{17}$ of the 318 patients complaining of pain from a cohort of 424 patients, half reported that pain started before ALS onset as low back pain, arthritis, headache, as pain from surgery, accident, injury, or cancer, or as other forms of pain. Nevertheless, $82 \%$ of the same sample reported that the pain experienced was due to ALS, and $34 \%$ that it was the presenting symptom of ALS. ${ }^{17}$ These figures, apparently lacking internal reliability, are likely explained by the evidence that most patients reported the worst pain as that of the past week, ${ }^{17}$ which possibly influenced their overall responses to the survey. However, no systematic studies on pain and cramps in the pre-diagnostic phase of ALS have been performed. Most recently, an epidemiological study ${ }^{53}$ showed that ALS patients at least two years before onset of the disease made more frequent use, compared to the general population, of central nervous system drugs (mainly gabapentin) commonly used as a treatment for neuropathic pain (hazard ratio 1.84; 95\% confidence interval 0.99-3.42), suggesting that sensory disturbances may precede the onset of motor impairment.

\section{Progression of pain through the disease course}

Although some studies suggested that pain is more frequent in the later stages of disease and found a correlation with the progression of functional impairment, ${ }^{14,15,18,21}$ others did not find a difference in frequency between the early and late phases of the disease, ${ }^{15,25}$ or emphasized a lack of correlation between ALS duration and pain severity. ${ }^{30,31}$ These differences among studies are mostly related to their cross-sectional design, which does not allow to identify the natural history of pain during the course of the disease. A longitudinal study on physical and psychological status in $\mathrm{ALS}^{54}$ which used the Visual Analogue Scale, found that pain intensity increased by 1 point from the first to the last visit, a median of 104 days later (range 35 to 846 days). This study showed that, in contrast to other symptoms such as depression and feeling of burden, patients and caregivers gave a similar rating of pain near the end of life. 
During the last month of life, $52 \%$ of patients have reported pain as present almost all the time or constant, and rated it as moderate or severe. ${ }^{55}$ Studies on ALS patients admitted to a hospice reported that pain was present in more than $75 \%$ of patients and that most of them had uncontrolled pain before the admission. ${ }^{56}$ The presence of pain, as assessed by the Bodily Pain domain of the Short Form (36) Health Survey (SF-36), did not influence the decision of ALS patients to accept or decline non-invasive ventilation (NIV). ${ }^{57}$ In a series of ALS patients treated with invasive ventilation (tracheostomy), the increase of pain and the need of sedative-analgesic drugs, together with cognitive-communication impairment, local infections and sepsis, pressure sores, and the need for indwelling catheters, were found to be events predicting the clinical deterioration leading to death. ${ }^{58}$ The frequency of pain and, to a lesser extent, its severity is one of the reasons for requesting access to euthanasia or assisted suicide in ALS patients. ${ }^{59,60}$

\section{Comorbidities}

The correlate of pain is reported to be, not unexpectedly, the deterioration in patients' quality of life. ${ }^{14,25}$ However, when depression is included as a covariate in the statistical analysis, the effect of pain intensity is no longer significant. ${ }^{31}$ Not surprisingly, pain is reported to be significantly more common in depressed ALS patients ${ }^{61}$ and depression to be more frequent in ALS patients complaining of pain. ${ }^{62}$ The co-presence of pain and depression has been reported to correlate with a poorer quality of life in ALS patients. ${ }^{31}$ Pain is known to have a high frequency among patients diagnosed with depression, with a prevalence of up to $75 \%,{ }^{63}$ and to interfere with physicians' ability to identify depression. ${ }^{64}$ On the other hand, depression has been recorded in up to $86 \%$ of patients with chronic pain. ${ }^{65}$ Therefore, the lack of data regarding mood disturbances in some studies that focused on pain in $\mathrm{ALS}^{14,15,18,30}$ may limit the interpretation of the results. This latter consideration may be true also for the larger group of neuromuscular diseases, including inherited myopathies and neuropathies, amongst which ALS patients were found to have a relatively lower frequency of pain, compared also with post-poliomyelitis syndrome. ${ }^{32}$ Depression is very frequent in neurodegenerative diseases ${ }^{66}$ including $A L S,{ }^{61,67}$ and at least $30 \%$ of ALS patients have been reported to follow anti-depressant therapy. ${ }^{61} \mathrm{~A}$ recent prospective study ${ }^{67}$ of a large ALS cohort followed-up for 8 years reported the occurrence of early moderate or moderate-severe depression in $47 \%$ of patients, which correlated with disease severity, and significantly impacted survival and quality of life. However, the study emphasized that depression did not progress along with motor deterioration, confirming previous findings on the lack of correlation between 
depression and duration of the disease. ${ }^{61}$ Considering the close correlation between mood disturbances and pain, this latter finding may explain why ALS patients are observed to complain of pain at any stage of the disease..$^{15,30,31}$

Differently from depression, other comorbid emotional symptoms, such has anxiety, apathy, and emotional lability, have never been studied in relation to pain in ALS.

In about $50 \%$ of ALS cases a comorbidity of motor symptoms with frontotemporal dementia (FTD) or milder form of cognitive impairment has been described. ${ }^{68}$ While no studies on pain in patients with comorbid ALS and FTD have been performed, a recent study showed that $40 \%$ of patients with pure behavioural variant FTD had blunted responsiveness to painful stimuli and temperature, particularly patients carrying the C9orf72 mutation. Using MRI voxel-based morphometry analysis pain and temperature symptoms were associated to a right-lateralized network including anterior temporal cortex, posterior thalamus and insula, indicating an altered processing of somatosensory signals. ${ }^{69}$ Such failure to interpret pain and temperature variations can put patients at risk of injuries. Due to the pathogenic relevance of C9orf72 mutation in ALS, this observation should be investigated in larger series of patients with C9orf72 mutations.

\section{Mechanisms of pain in ALS}

In patients with ALS, the relationship between the unpleasant sensory and emotional experiences that pain entails and the progressive degeneration of upper and lower motor neuron degeneration along with the involvement of other nervous system structure is poorly understood. According to the cross-sectional studies discussed, much of the chronic pain in ALS seems to result as a side effect of the motor impairment of ALS (i.e., secondary pain); however, this does not seem to explain all pain types in these patients. The pathophysiological origin of primary (mainly neuropathic) as well as secondary (mainly nociceptive) pain therefore needs to be explored, considering also the possibility of a maladaptive sensory response (central sensitisation) in these patients. Knowledge of the mechanisms of pain can be relevant in clinical practice to decide the analgesic treatments and, possibly, preventive strategies, and understanding of the pain type should be approached using currently accepted diagnostic criteria for neuropathic pain, ${ }^{70}$ nociceptive pain, ${ }^{71}$ and central sensitisation. ${ }^{72,73}$ 
Neuropathic pain. Prerequisite to the diagnosis of neuropathic pain is the evidence of a lesion or disease affecting the somatosensory system. ${ }^{70} \mathrm{CNS}$ sensory structures are generally spared in ALS, although the involvement of the posterior columns of the spinal cord has been demonstrated by neuropathological studies in some cases of familial $\mathrm{ALS}^{4,5}$ and by MRI alone ${ }^{6}$ or combined with somatosensory evoked potentials in some sporadic ALS patients. ${ }^{7}$ Clinically, there are occasional reports of sensory involvement. ${ }^{5,8,9}$ A Wallerian-like degeneration of dorsal root and dorsal funiculus axons has been described in the SOD1 mice model of $\mathrm{ALS}^{10}$

Based on the current definition of neuropathic pain, ${ }^{70}$ the evidence of sensory nerve fibre damage, if associated with a plausible clinical picture, could support the diagnosis of neuropathic pain. The distribution of symptom and signs should be used to define the level of certainty of neuropathic pain, and validated tests (e.g. nerve conduction studies and/or skin biopsy) should be used to demonstrate the relationship with a lesion or a disease. ${ }^{70}$ Sensory nerve conduction study (NCS) investigates large myelinated fibres transducing proprioceptive and touch sensation, whereas small unmyelinated and thinly myelinated nerve fibres conveying thermal and nociceptive stimuli can be easily examined by skin biopsy with quantification of intraepidermal nerve fibre (IENF) density (Panel 2). ${ }^{74}$

This approach, however, has not been systematically used for the assessment of neuropathic pain in ALS. Indeed, two clinical studies that have investigated the neuropathic origin of pain in ALS patients using questionnaires that can be used as discriminative or descriptive instruments, either did not find evidence for neuropathic pain ${ }^{25}$ or identified only a minority of patients with features of neuropathic pain (i.e., numbness, burning, tingling, etc, ${ }^{40}$ but did not confirm findings in these patients with nerve conduction studies or skin biopsies.

In studies of sensory nerve fibre damage, altered sensory NCS findings, most commonly subclinical, have been described in up to $30 \%$ of patients with an eventually confirmed diagnosis of $A L S,{ }^{9,75}$ although this percentage decreased to about $4 \%$ in more recent studies. ${ }^{28,29,76} \mathrm{~A}$ recent study ${ }^{77}$ suggested that sensory NCS abnormalities could be more frequently identified if distal nerves (e.g. dorsal sural and medial plantar) rather than conventional nerves (e.g. sural and median) are recorded, with 8 of 18 ALS patients showing abnormalities on conventional sensory NCS compared with 12 of 18 patients on distal sensory NCS.

The degeneration of IENF, which are terminal nociceptors, highly increases the risk of developing neuropathic pain in patients with peripheral neuropathy. ${ }^{74}$ Recent studies ${ }^{28,76}$ reported that more 
than $50 \%$ of ALS patients have small fibre neuropathy, but they did not investigate the correlation with pain ${ }^{76}$ or find a correlation with neuropathic pain as assessed by questionnaires. ${ }^{28}$ The study of a larger cohort of 51 ALS patients, including genetically defined cases, and 6 facial onset sensory and motor neuronopathy (FOSMN) patients, ${ }^{29}$ confirmed that small nerve pathology in part of the clinical picture in $75 \%$ of ALS cases but did not find any correlation with genotype, phenotype (e.g. bulbar versus spinal), duration of disease, disability, sensory NCS, sensory symptoms and, in particular, pain that 4 patients reported. A further study based on multiple skin biopsies confirmed these findings and demonstrated the asymptomatic involvement of autonomic nerves and Meissner corpuscles in ALS. ${ }^{26}$ The biological bases of IENF degeneration have been investigated in SOD $1^{\mathrm{G} 93 \mathrm{~A}}$ mouse models of ALS demonstrating that a misplacing of the peripherin specifically accumulates in small-size dorsal root ganglion neurons, from which IENF arise, and alters the homeostasis of neurofilaments. This phenomenon occurs since the asymptomatic phase of the disease, is likely intrinsic to its pathophysiology. ${ }^{11}$

Despite the evidence of damage to the somatosensory system based on NCS and skin biopsy findings, the lack of correlation with the clinical feature does not support the hypothesis that pain in most ALS patient may have a neuropathic nature, although further focused studies are warranted.

Nociceptive pain. Nociceptive pain is defined as arising from actual or threatening damage to nonneural tissue or from the activation of peripheral nociceptors in response to mechanical or other noxious stimuli. ${ }^{71}$ It is the most common type of pain that follows inflammatory conditions, surgery, arthrosis and traumatic injuries. Patients with impaired shoulder joint mobility due to upper arm weakness can suffer from typical nociceptive pain, whereas patients with chronic lowback pain can have a mixed neuropathic and nociceptive pain.

Based on the reports that pain in ALS is frequently associated with reduced mobility and skin pressure, and that more frequently involves extremities, back, shoulders and neck (panel $3),{ }^{14,15,17,20,21,30,31}$ it may be conceivable considering a predominantly nociceptive nature. This view is keeping also with the good response to non-steroidal anti-inflammatory drugs (NSAIDs) that are the first line of treatment of pain in ALS patients, ${ }^{24}$ and that are not effective in neuropathic pain. ${ }^{78}$ However, the nociceptive origin of pain in ALS has never been systematically investigated, and the diagnosis has been achieved by exclusion in studies primarily focused on neuropathic pain. ${ }^{25}$ Moreover, the hypothesis that pain in ALS may be caused by the reduced mobility should 
suggest a correlation with the duration of the disease that, however, is still a controversial issue. $^{14,15,17,40,79}$ Therefore, although some patients with evidence of tissue or joint damage can be definitely diagnosed with nociceptive pain, others might acquire an enhanced sensory response to normal inputs normally evoking innocuous sensations driven by central sensitization.

Central sensitisation. Basing the analysis of pain in ALS on the available literature, it becomes clear that neither neuropathic nor nociceptive mechanisms can completely explain its nature, occurrence and maintenance. A further phenomenon known as central sensitisation may play a role. Central sensitisation is currently thought to have a key role in various clinical conditions dominated by chronic pain ${ }^{80}$ including musculoskeletal disorders ${ }^{80}$ and is part of a newly proposed algorithm for chronic low back pain. ${ }^{81}$ It can complicate both neuropathic and nociceptive pain as the consequence of temporal, spatial and threshold changes of the signalling conveyed throughout the somatosensory system.

Two definitions are currently recognised: an amplification of neural signalling within the central nervous system that elicits pain hypersensitivity ${ }^{72}$ and an augmented responsiveness of central nervous system (CNS) neurons to normal or subthreshold afferent inputs that evoke innocuous sensations. ${ }^{73}$ Despite some intrinsic distinctions, both the definitions converge toward the concept of an abnormally enhanced nociceptive response in the CNS. Seminal papers ${ }^{82,83}$ have demonstrated that central sensitization can cause the spread of pain sensitivity across peripheral nerve territories, resulting in painful symptoms that are not necessarily driven by noxious stimuli or whose contribution was not necessary to produce pain, because they can induce a central amplification of sensory inputs determined by the state of excitability of CNS neurons. This complex networking is summarized by the concept of heterosynaptic potentiation that represents a condition where sensory inputs can amplify, even after have ended, subsequent responses of other non-stimulated non-nociceptive or nociceptive neurons that once triggered can persist over some time or require a very low level of nociceptive input to be maintained. ${ }^{72}$

No study has approached the issue of diffuse pain in ALS through the analysis of central sensitization, also due to the current lack of definite diagnostic tools. However, it would be a conceivable mechanism to consider based on the involvement of brain areas such as the prefrontal cortex, anterior cingulate cortex, insula, amygdala, thalamus and midbrain in chronic pain and in cognitive-emotional and affective processing of sensations, ${ }^{39}$ and whose functional impairment has been observed to occur also in ALS. ${ }^{84,85}$ 


\section{Treatment}

The ultimate need of ALS patients suffering from pain is to reduce its intensity and if possible prevent chronification of pain. After defining the cause of pain, the appropriate treatments including pharmacological and non-pharmacological interventions should be adopted, following guidelines when available, with the aim to provide patients with personalised therapies. Pharmacological treatments are the main approaches for neuropathic and other types of primary pain, in combination with non-pharmacological approaches for some symptoms such as spasticity, whereas non-pharmacological strategies are generally more effective for secondary sources of pain. A summary of pain treatments in ALS is reported in Table 1. 
Table 1: Studies of clinical use and effectiveness of pharmacological treatments for pain in ALS

\begin{tabular}{|c|c|c|c|c|c|c|c|c|c|}
\hline Drug & Study design & $\begin{array}{l}\text { Number patients } \\
\text { or centres }\end{array}$ & Results & Main target & Mechanisms of action & Posology & Side-effects & Contraindications & Comments \\
\hline \multicolumn{10}{|c|}{ Neuropathic pain (extremities)* } \\
\hline Gabapentin $^{78}$ & EFNS guidelines & N/A & $\begin{array}{l}\text { Effective in } \\
\text { various causes } \\
\text { of neuropathic } \\
\text { pain }\end{array}$ & $\begin{array}{l}\text { Voltage- } \\
\text { dependent } \\
\text { calcium channel } \\
\alpha 2 / \partial \text { subunits }\end{array}$ & $\begin{array}{l}\text { Inhibits voltage-gated } \\
\text { calcium channels; } \\
\text { decrease glutamate, } \\
\text { substance P and CGRP } \\
\text { release }^{86}\end{array}$ & $\begin{array}{l}900-3,600 \mathrm{mg} \\
\text { per day }\end{array}$ & $\begin{array}{l}\text { Dizziness, } \\
\text { fatigue, } \\
\text { drowsiness, } \\
\text { ataxia, } \\
\text { peripheral } \\
\text { oedema } \\
\text { nystagmus, } \\
\text { tremor, weight } \\
\text { gain }\end{array}$ & None & $\begin{array}{l}\text { Guidelines } \\
\text { focused on } \\
\text { neuropathic } \\
\text { pain of any } \\
\text { cause and not } \\
\text { on ALS }\end{array}$ \\
\hline Pregabalin $^{78}$ & EFNS guidelines & N/A & $\begin{array}{l}\text { Effective in } \\
\text { various causes } \\
\text { of neuropathic } \\
\text { pain }\end{array}$ & $\begin{array}{l}\text { Voltage-gated } \\
\text { calcium channel } \\
\alpha 2 / \partial \text { subunits }\end{array}$ & $\begin{array}{l}\text { Inhibits voltage-gated } \\
\text { calcium channels; } \\
\text { decreases glutamate } \\
\text { release; modulates } \\
\text { potassium channels }^{87}\end{array}$ & $\begin{array}{l}150-600 \mathrm{mg} \\
\text { per day }\end{array}$ & $\begin{array}{l}\text { Dizziness, } \\
\text { drowsiness, } \\
\text { peripheral } \\
\text { oedema, ataxia, } \\
\text { weight gain }\end{array}$ & None & $\begin{array}{l}\text { Guidelines } \\
\text { focused on } \\
\text { neuropathic } \\
\text { pain of any } \\
\text { cause and not } \\
\text { on ALS }\end{array}$ \\
\hline $\begin{array}{l}\text { Tricyclic } \\
\text { antidepressants }^{78}\end{array}$ & EFNS guidelines & N/A & $\begin{array}{l}\text { Effective in } \\
\text { various causes } \\
\text { of neuropathic } \\
\text { pain }\end{array}$ & & & $\begin{array}{l}50-100 \mathrm{mg} \\
\text { per day }\end{array}$ & $\begin{array}{l}\text { Dry mouth, } \\
\text { blurry vision, } \\
\text { constipation, } \\
\text { urinary } \\
\text { retention, } \\
\text { drowsiness }\end{array}$ & $\begin{array}{l}\text { Cardiac } \\
\text { arrhythmias; } \\
\text { prolonged Q-T } \\
\text { interval; prostate } \\
\text { hypertrophy; } \\
\text { closed angle } \\
\text { glaucoma }\end{array}$ & $\begin{array}{l}\text { Guidelines } \\
\text { focused on } \\
\text { neuropathic } \\
\text { pain of any } \\
\text { cause and not } \\
\text { on ALS }\end{array}$ \\
\hline \multicolumn{10}{|c|}{ Cramps (lower limbs, hands, abdomen)* } \\
\hline Quinine sulphate $e^{88}$ & $\begin{array}{l}\text { Systematic } \\
\text { review of } \\
\text { clinical trials }\end{array}$ & $\begin{array}{l}1,586 \text { participants } \\
\text { with cramps of } \\
\text { any cause }\end{array}$ & $\begin{array}{l}\text { Significant } \\
\text { reduction in } \\
\text { cramp number } \\
(28 \% ; 95 \% \mathrm{Cl} \\
15-40 \%), \\
\text { intensity (10\%; } \\
4-16 \%), \text { and } \\
\text { days (20\%; 6- } \\
33 \%) \text { over } 2 \\
\text { weeks }\end{array}$ & & & $\begin{array}{l}250-500 \mathrm{mg} \\
\text { per day }\end{array}$ & $\begin{array}{l}\text { Significantly } \\
\text { more minor } \\
\text { adverse events } \\
\text { in treatment } \\
\text { group (risk } \\
\text { difference }+3 \% \text {, } \\
95 \% \mathrm{Cl} 0 \% \text { to } \\
6 \% \text { ) }\end{array}$ & $\begin{array}{l}\text { Cardiac } \\
\text { arrhythmias; } \\
\text { bradycardia; } \\
\text { prolonged Q-T } \\
\text { interval; liver or } \\
\text { renal dysfunction; } \\
\text { hypokalemia }\end{array}$ & $\begin{array}{l}\text { FDA and AAN } \\
\text { have issued } \\
\text { safety } \\
\text { concerns } \\
\text { about use of } \\
\text { quinine } \\
\text { sulphate for } \\
\text { cramps }\end{array}$ \\
\hline Gabapentin $^{90}$ & $\begin{array}{l}\text { Phase 3 } \\
\text { randomised }\end{array}$ & $\begin{array}{l}204 \text { patients with } \\
\text { ALS }\end{array}$ & $\begin{array}{l}\text { No effect on } \\
\text { muscle cramps }\end{array}$ & & & $\begin{array}{l}\text { 900-3600 mg } \\
\text { per day }\end{array}$ & $\begin{array}{l}\text { Safe and well } \\
\text { tolerated. More }\end{array}$ & None & $\begin{array}{l}\text { Pain was not } \\
\text { an outcome }\end{array}$ \\
\hline
\end{tabular}




\begin{tabular}{|c|c|c|c|c|c|c|c|}
\hline & $\begin{array}{l}\text { double-blind } \\
\text { trial }\end{array}$ & & after 9 months & & $\begin{array}{l}\text { common side } \\
\text { effects in } \\
\text { gabapentin } \\
\text { treated patients } \\
\text { were light } \\
\text { headedness, } \\
\text { drowsiness, falls } \\
\text { and limb } \\
\text { swelling }\end{array}$ & & $\begin{array}{l}\text { measure in } \\
\text { this study }\end{array}$ \\
\hline Mexiletine $^{91}$ & $\begin{array}{l}\text { Phase } 2 \\
\text { randomised } \\
\text { placebo- } \\
\text { controlled study }\end{array}$ & $\begin{array}{l}60 \text { patients with } \\
\text { ALS }\end{array}$ & $\begin{array}{l}\text { Significant } \\
\text { dose- } \\
\text { dependent } \\
\text { reductions in } \\
\text { cramp } \\
\text { frequency ( } 300 \\
\text { mg per day: } \\
31 \%, p=0.047 ; \\
900 \mathrm{mg} \text { per day: } \\
16 \%, p=0.002 \text { ) } \\
\text { and intensity } \\
\text { (300 mg per } \\
\text { day: } 45 \% \\
p=0.08 ; 900 \mathrm{mg} \\
\text { per day: } 25 \%, \\
\mathrm{p}=0.005 \text { ) }\end{array}$ & $\begin{array}{l}300-900 \mathrm{mg} \\
\text { per day }\end{array}$ & $\begin{array}{l}\text { Safe and well } \\
\text { tolerated at } 300 \\
\text { mg per day; } \\
\text { adverse effects } \\
\text { at } 900 \mathrm{mg} \text { per } \\
\text { day led to high } \\
\text { rate of } \\
\text { discontinuation }\end{array}$ & $\begin{array}{l}\text { Cardiac } \\
\text { arrhythmias; } \\
\text { atrioventricular } \\
\text { block }\end{array}$ & $\begin{array}{l}\text { Pain was not } \\
\text { an outcome } \\
\text { measure in } \\
\text { this study }\end{array}$ \\
\hline $\begin{array}{l}\text { Tetrahydrocannabi } \\
\text { nol }^{92}\end{array}$ & $\begin{array}{l}\text { Phase } 2 \\
\text { randomized } \\
\text { double-blind } \\
\text { crossover trial }\end{array}$ & $\begin{array}{l}27 \text { patients with } \\
\text { ALS }\end{array}$ & $\begin{array}{l}\text { No effect on } \\
\text { cramp intensity } \\
\text { and number }\end{array}$ & $5 \mathrm{mg}$ bid & $\begin{array}{l}\text { Two non-drug } \\
\text { related serious } \\
\text { side effects, one } \\
\text { patient had } \\
\text { mild dizziness }\end{array}$ & $\begin{array}{l}\text { Co-morbid mental } \\
\text { disorders }\end{array}$ & $\begin{array}{l}\text { Pain was not } \\
\text { an outcome } \\
\text { measure in } \\
\text { this study }\end{array}$ \\
\hline Levetiracetam $^{93}$ & $\begin{array}{l}\text { Open-label pilot } \\
\text { trial }\end{array}$ & $\begin{array}{l}20 \text { patients with } \\
\text { ALS }\end{array}$ & $\begin{array}{l}\text { Significant } \\
\text { reduction in } \\
\text { cramps after } 9 \\
\text { months ( } 1500 \\
\text { mg bid, } \\
\text { reduction of the } \\
\text { Cramp Severity } \\
\text { Scale score, } \\
p<0.01 \text { ) }\end{array}$ & $1500 \mathrm{mg}$ bid & $\begin{array}{l}\text { Fatigue, } \\
\text { somnolence, } \\
\text { headache, } \\
\text { insomnia }\end{array}$ & $\begin{array}{l}\text { Severe mood } \\
\text { depression }\end{array}$ & $\begin{array}{l}\text { Pain was not } \\
\text { an outcome } \\
\text { measure in } \\
\text { this study }\end{array}$ \\
\hline \multicolumn{8}{|c|}{ Spasticity (lower limbs)* } \\
\hline Levetiracetam $^{93}$ & $\begin{array}{l}\text { Open-label pilot } \\
\text { trial }\end{array}$ & $\begin{array}{l}20 \text { patients with } \\
\text { ALS }\end{array}$ & $\begin{array}{l}\text { Significant } \\
\text { reduction in } \\
\text { spasticity after }\end{array}$ & $\begin{array}{l}\text { 1500-3000 mg } \\
\text { per day }\end{array}$ & $\begin{array}{l}\text { Fatigue, } \\
\text { somnolence, } \\
\text { headache, }\end{array}$ & None & $\begin{array}{l}\text { Pain was not } \\
\text { an outcome } \\
\text { measure in }\end{array}$ \\
\hline
\end{tabular}




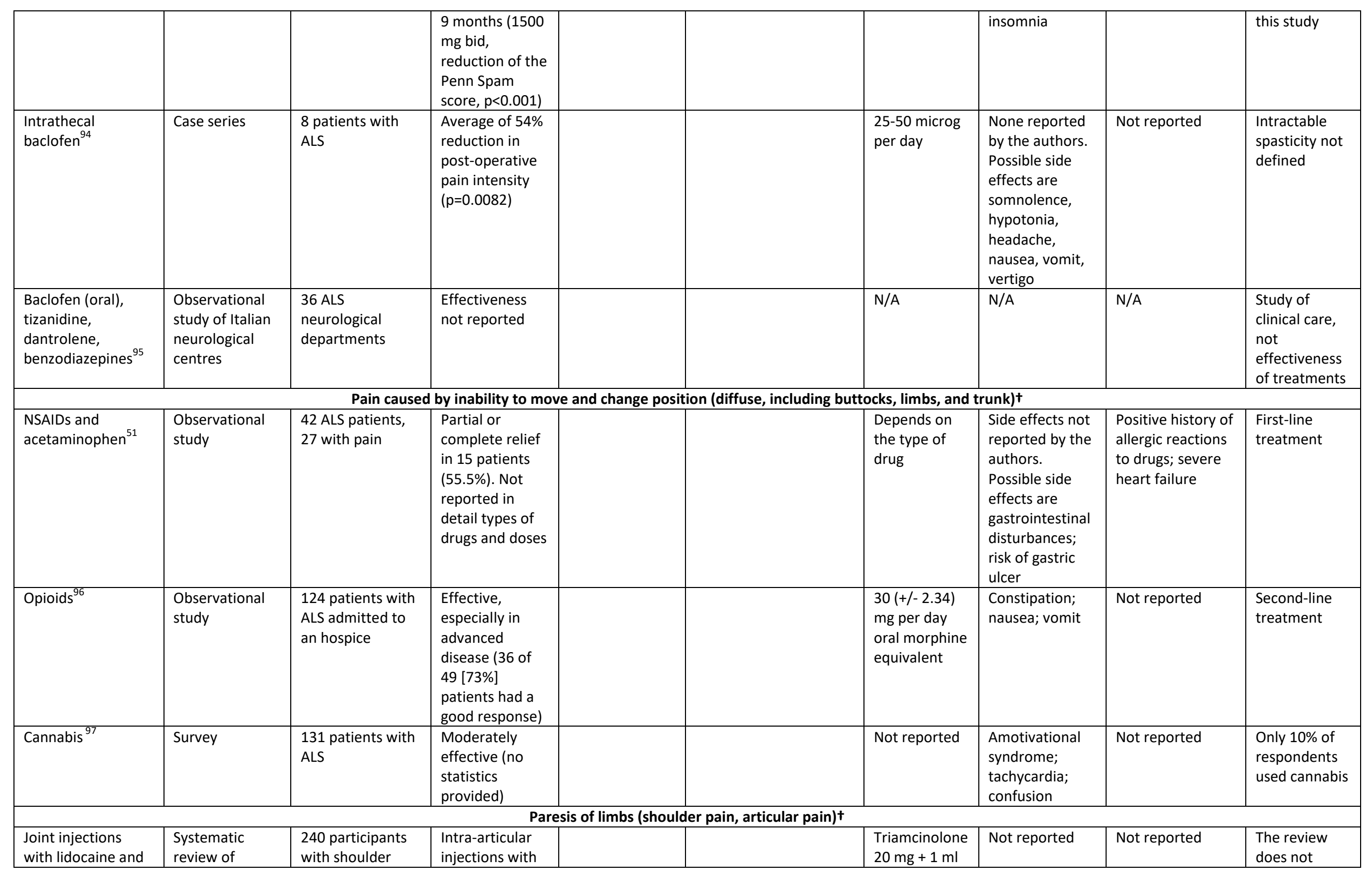




\begin{tabular}{|c|c|c|c|c|c|c|c|}
\hline steroids $^{98}$ & clinical trials & $\begin{array}{l}\text { pain of any cause } \\
\text { ( } 2 \text { trials) }\end{array}$ & $\begin{array}{l}\text { lidocaine and } \\
\text { steroids better } \\
\text { than } \\
\text { physiotherapy }\end{array}$ & $2 \%$ lidocaine & & & $\begin{array}{l}\text { include ALS } \\
\text { patients }\end{array}$ \\
\hline $\begin{array}{l}\text { Intra-articular } \\
\text { steroid injection vs } \\
\text { physiotherapy } \\
\text { (mobilization, } \\
\text { exercise and } \\
\text { electrotherapy) }\end{array}$ & $\begin{array}{l}\text { Systematic } \\
\text { review of } \\
\text { clinical trials }\end{array}$ & $\begin{array}{l}109 \text { participants } \\
\text { with adhesive } \\
\text { capsulitis ( } 2 \text { trials) }\end{array}$ & $\begin{array}{l}\text { Steroid } \\
\text { injections more } \\
\text { effective then } \\
\text { physiotherapy }\end{array}$ & $\begin{array}{l}\text { Triamcinolone } \\
20 \mathrm{mg}\end{array}$ & $\begin{array}{l}\text { Pain after } \\
\text { treatment, skin } \\
\text { irritation, facial } \\
\text { flushing }\end{array}$ & Not reported & $\begin{array}{l}\text { The review } \\
\text { does not } \\
\text { include ALS } \\
\text { patients }\end{array}$ \\
\hline
\end{tabular}

In view of the evidence, the Practice Parameters of the American Academy of Neurology ${ }^{22}$ and the European guidelines on the Clinical Management of ALS recommend that pain management in ALS is based on clinical experience. ${ }^{23}$ *Primary forms of pain. +Secondary (mainly nociceptive) forms of pain. NSAIDs, nonsteroidal anti-inflammatory agents. All studies involving ALS patients have been reviewed. When no studies on ALS patients were available, the most recent general reviews or expert opinions on the topic have been reported. 


\section{Pharmacological treatments (Table 1)}

A recent Cochrane review ${ }^{24}$ assessed the efficacy of pharmacological treatment for primary and secondary pain in ALS based on the analysis of case series with more than 5 patients published up till 2012, along with several other case series reporting less than five patients. The authors concluded that there was no evidence from randomized controlled trials (RTCS) about the management of pain in ALS. In two surveys on ALS centres the most commonly used drugs for pain in ALS were NSAIDs and acetaminophen for secondary pain, and medications for primary neuropathic pain (gabapentin, pregabalin, tricyclic antidepressants). ${ }^{95,99}$ Opioids were the second option when pain was not controlled. Opioids are required particularly in advanced stages to control increased pain and symptoms related to respiratory insufficiency, such as dyspnoea and poor sleep. However, the review ${ }^{24}$ emphasized the lack of reliable data for use of opioids in ALS that was even more evident for the analysis of efficacy. There is indeed no study in patients with ALS on the drugs recommended for neuropathic pain, ${ }^{78}$ and only two surveys on the use of cannabinoids for neuropathic and nociceptive pain. ${ }^{97,100}$ Cannabis may be effective in reducing pain, and can act in synergy with opioids. Although of interest from an epidemiological perspective, these surveys cannot provide information for clinical practice. Thus, the current management of pain in ALS remains based on physicians' experience rather than on proper guidelines, as reflected in the recommendations provided by the Practice Parameters of the American Academy of Neurology ${ }^{22}$ and the European guidelines on the Clinical Management of ALS. $^{23}$

Data from surveys, open and randomized clinical trials are available on the treatment of cramps in ALS. Quinine sulphate is the most used drug for cramps, though with caution for several possible serious side effects (e.g. thrombocytopenia) and drug interactions. ${ }^{99}$ In U.S. Food and Drug Administration has issued safety announcements that quinine sulphate is only approved for the 
treatment of malaria and not approved for the treatment or prevention of leg cramps (Baldinger et al). The superior efficacy of quinine sulphate against cramps compared to placebo or other interventions has been suggested in a Cochrane review that included several etiologies, ${ }^{88}$ but studies of the effects of quinine sulphate on cramps in ALS specifically have not been done. ${ }^{89} \mathrm{~A}$ recent phase II randomized placebo-controlled study showed that treatment with mexiletine resulted in a significant dose-dependent reduction in muscle cramp frequency and severity and was well tolerated at the dose of $300 \mathrm{mg} / \mathrm{d} .{ }^{91}$ Conversely, a randomized, double-blind, placebocontrolled crossover trial on tetrahydrocannabinol given at the dose of $5 \mathrm{mg}$ bid failed to demonstrate an efficacy on cramps in ALS, although the drug was well tolerated. ${ }^{92}$ Gabapentin did not demonstrate efficacy in slowing the rate of muscle strength decline in ALS patients and in this context no efficacy against cramps was reported. ${ }^{90}$ A study reported a possible positive effect of levetiracetam on cramps and spasticity in ALS, but this finding is limited by the non-controlled and open design of the trial. ${ }^{93}$

There is no controlled clinical trial on the efficacy of drugs to treat spasticity in ALS. Most ALS physicians in Italy use baclofen, followed by tizanidine, benzodiazepines and dantrolene. ${ }^{95}$ Another European survey reported the widespread use of carbamazepine. ${ }^{99}$ A small study on 8 patients with spasticity-related intractable pain referred for intrathecal baclofen (ITB) pump placement reported a $54 \%$ average reduction in post-operative pain intensity based on a 0 to 10 rating score in six patients. ${ }^{94}$ This finding is limited, however, by the open-label design of the study and by the lack of follow-up data precluding analysis of ITB's long-term efficacy on pain.

\section{Non-pharmacological treatments (Table 2)}

Regular stretching and passive and/or active range-of-motion exercises are safe and effective in preventing spasticity. ${ }^{101}$ These approaches are also useful for treating secondary pain resulting 
from motor degeneration, including musculoskeletal pain, and for maintaining muscle length and physical mobility. ${ }^{101}$ For example, a timely, regular program of stretching and range-of-motion exercises could prevent occurrence of shoulder pain. ${ }^{101}$ An open-label, randomized, parallel study (NCT01521728) on resistance and endurance exercise, and stretching/range-of-motion in a series of ALS patients has been recently completed and its results are awaited. Osteopathic manual treatment showed some efficacy in the treatment of pain in a small open-label study. ${ }^{102}$ Other less commonly used interventions for secondary forms of pain include warm and cold compresses, transcutaneous electrical nerve stimulation, acupuncture, joint injections with lidocaine and steroids. ${ }^{98,103}$ Many types of assistive devices can be used to prevent pain caused by reduced mobility, including special mattresses and pillows, and custom-fitted wheelchairs. Neutral position splints for hands and ankles are effective in reducing joint contractures. ${ }^{101}$ Patients and caregivers should be trained to appropriately use transfer techniques and devices like canes and walkers in order to prevent falls and injuries. Remedies for complications related to NIV include changing the mask before the appearance of pressure-related skin changes (e.g. using nasal mask or pillows during the day and orofacial mask during the night) and use of special dermal application materials. $^{104}$

The interest in alternative therapies is increasing in recent years and is particularly popular in Eastern countries. ${ }^{105-107}$ In China, there is widespread use in ALS patients of integrative therapies such as vitamins, herb decoctions and compounds, acupuncture, yoga, and massage therapy. ${ }^{107}$ The efficacy of these therapies in relieving symptoms, in particular pain, has not been studied yet. 
Table 2: Studies of clinical use and effectiveness of non-pharmacological strategies for pain in ALS

\begin{tabular}{|c|c|c|c|c|c|}
\hline & Study design & Number of patients/centres & Results & Contraindications & Comments \\
\hline \multicolumn{6}{|c|}{ Cramps (lower limbs, hands, abdomen)* } \\
\hline Stretching ${ }^{101}$ & $\begin{array}{l}\text { Review of } \\
\text { published work } \\
\text { and case studies }\end{array}$ & 3 patients with ALS & Clinically effective & Not reported & $\begin{array}{l}\text { Based mainly on } \\
\text { clinical experience }\end{array}$ \\
\hline Massaging $^{108}$ & $\begin{array}{l}\text { Review of } \\
\text { published work }\end{array}$ & N/A & Clinically effective & Not reported & $\begin{array}{l}\text { Based mainly on } \\
\text { clinical experience }\end{array}$ \\
\hline \multicolumn{6}{|c|}{ Spasticity (lower limbs)* } \\
\hline $\begin{array}{l}\text { Moderate physical } \\
\text { activity }^{109}\end{array}$ & Randomised trial & 25 patients with ALS & $\begin{array}{l}\text { Significantly less deterioration on ALS } \\
\text { Functional Rating Scale }(p<0.001) \text { and } \\
\text { Ashworth Spasticity Scale }(p=0.005) \\
\text { after } 3 \text { months but no difference after } \\
6 \text { months. No effect on pain }\end{array}$ & None reported & \\
\hline $\begin{array}{l}\text { Daily stretching, } \\
\text { assistive ROM } \\
\text { exercises }^{101}\end{array}$ & $\begin{array}{l}\text { Review of } \\
\text { published work } \\
\text { and case studies }\end{array}$ & 3 patients with ALS & Clinically effective & $\begin{array}{l}\text { Avoid high-resistance } \\
\text { exercise, select a mode of } \\
\text { exercise with minimal risk of } \\
\text { injury from falling }\end{array}$ & $\begin{array}{l}\text { Based mainly on } \\
\text { clinical experience }\end{array}$ \\
\hline \multicolumn{6}{|c|}{ Pain caused by inability to move and change position (diffuse, including buttocks, limbs and trunk) $\dagger$} \\
\hline $\begin{array}{l}\text { Osteopathic manual } \\
\text { treatment }^{102}\end{array}$ & $\begin{array}{l}\text { Feasibility pilot } \\
\text { study }\end{array}$ & 14 patients with ALS & $\begin{array}{l}\text { Single-blind trial comparing } \\
\text { osteopathic manual treatment (OMT) } \\
\text { vs usual care followed by an OMT } \\
\text { open period. Mild reduction of pain at } \\
\text { the Pain Severity Index }(p=0.05)\end{array}$ & None reported & Small pilot study \\
\hline $\begin{array}{l}\text { Daily stretching, } \\
\text { assistive ROM } \\
\text { exercises, } \\
\text { wheelchairs, } \\
\text { orthoses }^{101}\end{array}$ & $\begin{array}{l}\text { Review of } \\
\text { published work } \\
\text { and case studies }\end{array}$ & 3 patients with ALS & Clinically effective & $\begin{array}{l}\text { Avoid high-resistance } \\
\text { exercise, select a mode of } \\
\text { exercise with minimal risk of } \\
\text { injury from falling }\end{array}$ & $\begin{array}{l}\text { Based mainly on } \\
\text { clinical experience }\end{array}$ \\
\hline \multicolumn{6}{|c|}{ Paresis of limbs (shoulder pain, articular pain)† } \\
\hline $\begin{array}{l}\text { Range of } \\
\text { physiotherapy } \\
\text { interventions (e.g., } \\
\text { transcutaneous }\end{array}$ & $\begin{array}{l}\text { Systematic } \\
\text { review of clinical } \\
\text { trials }\end{array}$ & $\begin{array}{l}\text { Ultrasound vs. placebo (general } \\
\text { shoulder pain, } 73 \text { treated, } 72 \\
\text { placebo) } \\
\text { Ultrasound vs. placebo (calcific }\end{array}$ & $\begin{array}{l}\text { Ultrasound vs. placebo (general } \\
\text { shoulder pain): non effective } \\
\text { Ultrasound vs. placebo (calcific } \\
\text { tendinitis): moderately effective (risk }\end{array}$ & & $\begin{array}{l}\text { Varied quality of trials } \\
\text { prevented firm } \\
\text { conclusions from being } \\
\text { drawn }\end{array}$ \\
\hline
\end{tabular}




\begin{tabular}{|c|c|c|c|c|c|}
\hline $\begin{array}{l}\text { electrical nerve } \\
\text { stimulation, } \\
\text { stretching, range-of } \\
\text { motion, massage, } \\
\text { laser therapy) }\end{array}$ & & $\begin{array}{l}\text { tendinitis, } 32 \text { treated, } 29 \\
\text { placebo) } \\
\text { Supervised exercises (rotator } \\
\text { cuff disease, } 45 \text { treated, } 28 \\
\text { placebo) } \\
\text { Laser therapy (adhesive } \\
\text { capsulitis, } 20 \text { treated, } 20 \\
\text { placebo) } \\
\text { Laser therapy ( } 2 \text { trials, } \\
\text { supraspinatus tendinitis, } 28 \\
\text { treated, } 24 \text { placebo) } \\
\text { lontoforesis with acetic acid } \\
\text { plus ultrasound (11 treated, } 10 \\
\text { not treated) } \\
\text { Mobilization plus exercise vs } \\
\text { exercise alone (17 vs } 17 \text { ) } \\
\text { Isokinetic resistance exercises } \\
\text { vs. electromyographic } \\
\text { biofeedback (11 vs 9) }\end{array}$ & $\begin{array}{l}\text { ratio, } 4.53 \text { ) } \\
\text { Supervised exercises: moderately } \\
\text { effective (risk ratio, } 2.45 \text { ) } \\
\text { Laser therapy (adhesive tendinitis): } \\
\text { effective (risk ratio, } 8.00 \text { ) } \\
\text { Laser therapy (supraspinatus } \\
\text { tendinitis): not effective } \\
\text { lontoforesis with acetic acid plus } \\
\text { ultrasound (calcific tendinitis): not } \\
\text { effective } \\
\text { Mobilization plus exercise vs exercise } \\
\text { alone (adhesive capsulitis and rotator } \\
\text { cuff impingement): no difference } \\
\text { Isokinetic resistance exercises vs. } \\
\text { electromyographic biofeedback } \\
\text { (anterior instability): no difference }\end{array}$ & & \\
\hline Acupuncture $^{103}$ & $\begin{array}{l}\text { Systematic } \\
\text { review of clinical } \\
\text { trials }\end{array}$ & $\begin{array}{l}9 \text { trials of participants with } \\
\text { shoulder pain of any cause } \\
\text { ( } n \geq 18 \text { in each study) }\end{array}$ & $\begin{array}{l}\text { Evidence suggests no effect or possible } \\
\text { short-term benefit (over } 2-4 \text { weeks). }\end{array}$ & None reported & $\begin{array}{l}\text { Varied quality of trials } \\
\text { prevented firm } \\
\text { conclusions from being } \\
\text { drawn }\end{array}$ \\
\hline $\begin{array}{l}\text { Assistive ROM } \\
\text { exercises }^{101}\end{array}$ & $\begin{array}{l}\text { Review of } \\
\text { published work } \\
\text { and case studies }\end{array}$ & 3 patients with ALS & Clinically effective & $\begin{array}{l}\text { Caregiver participation } \\
\text { needed when muscle } \\
\text { weakness prevents the } \\
\text { patient from performing } \\
\text { program independently }\end{array}$ & $\begin{array}{l}\text { Based mainly on } \\
\text { clinical experience }\end{array}$ \\
\hline \multicolumn{6}{|c|}{ Joint contractures (hand and ankle joints)t } \\
\hline $\begin{array}{l}\text { Neutral-position } \\
\text { splints for hands and } \\
\text { ankles }^{101}\end{array}$ & $\begin{array}{l}\text { Review of } \\
\text { published work } \\
\text { and case studies }\end{array}$ & 3 patients with ALS & $\begin{array}{l}\text { Can supplement stretching and ROM } \\
\text { exercises }\end{array}$ & None reported & $\begin{array}{l}\text { Based mainly on } \\
\text { clinical experience }\end{array}$ \\
\hline
\end{tabular}

In view of the evidence, the Practice Parameters of the American Academy of Neurology 22 and the European guidelines on the Clinical Management of ALS recommend that pain management in ALS is based on clinical experience. ${ }^{23}{ }^{*}$ Primary forms of pain. + Secondary (mainly nociceptive) forms of pain. ROM, range of motion.

All studies involving ALS patients have been reviewed. When no studies on ALS patients were available, the most recent general reviews on the topic have been reported 


\section{Conclusions and future perspectives}

ALS patients can suffer from pain due to a variety of causes including reduced mobility, cramps and spasticity. On the basis of the available literature, pain should be considered as a condition that: 1) can complicate the course of ALS in a percentage of patients that varies according to the definition of pain used and the analysis or not of mood comorbidities, 2) can occur throughout the course of the disease, 3) commonly has a mild intensity, with the possible exception of late-stages of the disease, and 4) can significantly undermine, along with depression, patients' quality of life.

The prevalence of pain in ALS is still not completely clear, due both to the scarcity of focused studies and the heterogeneous methodologies used. Longitudinal studies on onset and course of pain and cramps in large series of patients are therefore needed, as are studies focused on the impact of co-morbid cognitive impairment on pain perception, which might affect the results of epidemiological studies. Moreover, research aiming to identify the individual susceptibility of ALS patients to develop chronic pain including risk relating to personal, socioeconomic, genetic and disease-related factors is needed. Pain may be more frequent in patients with spinal

presentation, ${ }^{14,15,41}$ but the lack of predictive biomarkers hinders the possibility of identifying those patients at higher risk. Another area to consider in future ALS studies is the assessment of different types of pain (e.g. neuropathic, nociceptive) and the role of central sensitization, and their prevalence and impact on patients' management and quality of live during the course of the disease. It would also be useful to understand factors that influence disease prognosis, such as sensory changes.

The heterogeneity of the mechanisms at the base of the diverse manifestations of pain in ALS, and the variable and unpredictable progression of the disease, underscores the need for an individually tailored and multidisciplinary approach to its management. Careful and timely evaluations are necessary for a correct management of pain, particularly in the later stages when patients experience respiratory failure and severe reduced mobility. Guidelines on pain ascertainment, including the identification of rating scales to be used in the clinical setting are needed. The frequent association between pain and depression can further worsen the quality of life of ALS patients. Thus, a thorough knowledge of the patient's physical and psychological conditions, including anxiety and emotional lability, is essential for the management of each patient as an individual. Pharmacological treatment can be useful for some primary pain types, mainly neuropathic, and physical therapy may have a role in preventing and treating pain in ALS. 
Pain treatment has also positive psychological effects on ALS patients, thus affecting patient and carer quality of life. However, specific guidelines on the management of pain in ALS patients are lacking, and the results of the few clinical trials published on cramps and spasticity were disappointing. Several treatments often used by patients to relieve pain, both prescribed by physicians and self-prescribed, including physical therapy approaches and non-conventional treatments, never underwent formal randomized trials. Trials on both pharmacological and nonpharmacological treatments in different types of pain with appropriate methodology and outcome measures are therefore warranted to evaluate safety and establish efficacy. Pharmacogenomics studies would be also useful to identify gene variants associated with different response to analgesics and side effects. When the classical placebo-controlled double-blind design is not feasible, for example in evaluating non-pharmacological treatments, alternative designs should be considered, such as the use of waiting list controls ${ }^{110}$ or blinded assessment of outcome. ${ }^{111}$ Until results from more robust treatment studies are available, treatment should be based on good clinical practice backed up by available guidelines on non-malignant chronic pain. 


\section{Contributors}

AC coordinated authors' writing, revision, and editing, wrote the first draft, and finalized the manuscript. AC did the literature search and contributed to sections on epidemiology of pain, assessment of pain in the clinical setting, characteristics of pain in ALS and relation to comorbidities, Table 2, and the description of case study 1; GL did the literature search and contributed to sections on mechanisms of pain, pain and ALS genetics, Table 1, and the description of case study 2; GM did the literature search and contributed to the section on treatment and the description of case study 3. All authors were involved in critical revision of the manuscript and in the preparation of the Figure.

\section{Funding sources}

This review has been partly founded by the Joint Programme - Neurodegenerative Disease Research (ALS-CARE, supported by the Italian Ministry of Health [to GM], and by the Italian Ministry of University and Research [to AC]).

\section{Declaration of interests}

AC has served on scientific advisory boards for Biogen Idec, Cytokinetics, Italfarmaco, Neuraltus, Mitsubishi Tanabe; and has received research support from the Italian Ministry of Health, Italian Ministry of Education University and Research, European Commission, Compagnia di San Paolo, Agenzia Italiana per la Ricerca sulla SLA (ARISLA), Fondazione Vialli e Mauro Onlus, and Associazione Piemontese per l'Assistenza alla SLA (APASLA). GM has received research support from the Italian Ministry of Health, European Commission, and Agenzia Italiana per la Ricerca sulla SLA (ARISLA). GL has served on scientific advisory board for Johnson \& Johnson, Mitsubishi, Shire International, Glaxo-Smith-Klein, Boehringer, Kedrion, Baxalta, and has received research support from the Italian Ministry of Health, European Commission, Agenzia Italiana per la Ricerca sulla SLA (ARISLA), Fondazione Vialli e Mauro Onlus.

\section{Search strategy and selection criteria}

We searched PubMed (1966, to October 25, 2016), Embase (1980, to October 25, 2016), and the Cochrane Library (April, 1996, to October 25, 2016) for relevant titles using the terms "amyotrophic lateral sclerosis" or "motor neuron disease" or "primary lateral sclerosis" in combination with "pain", "sensory symptoms", "cramps", "pain therapy", and "opioids". Further 
material was gathered from reference lists, review articles, and major textbook chapters. We also included abstracts and reports from relevant meetings. The final reference list was generated on the basis of originality and relevance to the topics covered in this report. Emphasis was placed on publications from the past 10 years, but we did not exclude commonly referenced and highly regarded older publications.

\section{References}

1. Kiernan MC, Vucic S, Cheah BC, et al. Amyotrophic lateral sclerosis. Lancet 2011; 377(9769): 942-55.

2. Canosa A, Pagani M, Cistaro A, et al. 18F-FDG-PET correlates of cognitive impairment in ALS. Neurology 2016; 86(1): 44-9.

3. Chio A, Brunetti M, Barberis $\mathrm{M}$, et al. The Role of APOE in the Occurrence of Frontotemporal Dementia in Amyotrophic Lateral Sclerosis. JAMA Neurol 2016; 73(4): 425-30.

4. Kato S, Kawata A, Oda M, Arai N, Komori T, Tanabe H. Absence of SOD1 gene abnormalities in familial amyotrophic lateral sclerosis with posterior column involvement without Lewy-body-like hyaline inclusions. Acta Neuropathol 1996; 92(5): 528-33.

5. Wakabayashi K, Horikawa Y, Oyake M, Suzuki S, Morita T, Takahashi H. Sporadic motor neuron disease with severe sensory neuronopathy. Acta Neuropathol 1998; 95(4): 426-30.

6. Cohen-Adad J, Zhao W, Keil B, et al. 7-T MRI of the spinal cord can detect lateral corticospinal tract abnormality in amyotrophic lateral sclerosis. Muscle Nerve 2013; 47(5): 760-2.

7. Iglesias C, Sangari S, El Mendili MM, Benali H, Marchand-Pauvert V, Pradat PF. Electrophysiological and spinal imaging evidences for sensory dysfunction in amyotrophic lateral sclerosis. BMJ Open 2015; 5(2): e007659.

8. Isaacs JD, Dean AF, Shaw CE, Al-Chalabi A, Mills KR, Leigh PN. Amyotrophic lateral sclerosis with sensory neuropathy: part of a multisystem disorder? J Neurol Neurosurg Psychiatry 2007; 78(7): 750-3.

9. Pugdahl K, Fuglsang-Frederiksen A, de Carvalho M, et al. Generalised sensory system abnormalities in amyotrophic lateral sclerosis: a European multicentre study. J Neurol Neurosurg Psychiatry 2007; 78(7): 746-9.

10. Guo YS, Wu DX, Wu HR, et al. Sensory involvement in the SOD1-G93A mouse model of amyotrophic lateral sclerosis. Exp Mol Med 2009; 41(3): 140-50.

11. Sassone J, Taiana M, Lombardi R, et al. ALS mouse model SOD1G93A displays early pathology of sensory small fibers associated to accumulation of a neurotoxic splice variant of peripherin. Hum Mol Genet 2016; 25(8): 1588-99.

12. Wicks P. Reassessing received wisdom in ALS--pain is common when studied systematically. Eur J Neurol 2012; 19(4): 531-2.

13. Handy CR, Krudy C, Boulis N, Federici T. Pain in amyotrophic lateral sclerosis: a neglected aspect of disease. Neurol Res Int 2011; 2011: 403808.

14. Chio A, Canosa A, Gallo S, et al. Pain in amyotrophic lateral sclerosis: a population-based controlled study. Eur J Neurol 2012; 19(4): 551-5.

15. Rivera I, Ajroud-Driss S, Casey P, et al. Prevalence and characteristics of pain in early and late stages of ALS. Amyotroph Lateral Scler Frontotemporal Degener 2013; 14(5-6): 369-72.

16. Moisset X, Cornut-Chauvinc C, Clavelou P, Pereira B, Dallel R, Guy N. Is there pain with neuropathic characteristics in patients with amyotrophic lateral sclerosis? A cross-sectional study. Palliat Med 2015.

17. Stephens HE, Lehman E, Raheja D, et al. Pain in amyotrophic lateral sclerosis: Patient and physician perspectives and practices. Amyotroph Lateral Scler Frontotemporal Degener 2015; 17(1-2): 21-9.

18. Raheja D, Stephens HE, Lehman E, Walsh S, Yang C, Simmons Z. Patient-reported problematic symptoms in an ALS treatment trial. Amyotroph Lateral Scler Frontotemporal Degener 2016: 1-8.

19. Drake ME, Jr. Chronic pain syndrome in amyotrophic lateral sclerosis. Arch Neurol 1983; 40(7): 453-

4. 
20. de Castro-Costa CM, Oria RB, Machado-Filho JA, et al. Amyotrophic lateral sclerosis. Clinical analysis of 78 cases from Fortaleza (northeastern Brazil). Arquivos de neuro-psiquiatria 1999; 57(3B): 761-74.

21. Ganzini L, Johnston WS, Hoffman WF. Correlates of suffering in amyotrophic lateral sclerosis. Neurology 1999; 52(7): 1434-40.

22. Miller RG, Jackson CE, Kasarskis EJ, et al. Practice parameter update: the care of the patient with amyotrophic lateral sclerosis: multidisciplinary care, symptom management, and cognitive/behavioral impairment (an evidence-based review): report of the Quality Standards Subcommittee of the American Academy of Neurology. Neurology 2009; 73(15): 1227-33.

23. Andersen PM, Abrahams S, Borasio GD, et al. EFNS guidelines on the clinical management of amyotrophic lateral sclerosis (MALS)--revised report of an EFNS task force. Eur J Neurol 2012; 19(3): 360-75.

24. Brettschneider J, Kurent J, Ludolph A. Drug therapy for pain in amyotrophic lateral sclerosis or motor neuron disease. Cochrane Database Syst Rev 2013; 6: CD005226.

25. Wallace VC, Ellis CM, Burman R, Knights C, Shaw CE, Al-Chalabi A. The evaluation of pain in amyotrophic lateral sclerosis: a case controlled observational study. Amyotroph Lateral Scler Frontotemporal Degener 2014; 15(7-8): 520-7.

26. Nolano $\mathrm{M}$, Provitera $\mathrm{V}$, Manganelli $\mathrm{F}$, et al. Nonmotor involvement in amyotrophic lateral sclerosis: new insight from nerve and vessel analysis in skin biopsy. Neuropathol Appl Neurobiol 2016.

27. Vucic S. Sensory and autonomic nervous system dysfunction in amyotrophic lateral sclerosis. Neuropathol Appl Neurobiol 2016.

28. Truini A, Biasiotta A, Onesti E, et al. Small-fibre neuropathy related to bulbar and spinal-onset in patients with ALS. J Neurol 2015; 262(4): 1014-8.

29. Dalla Bella E, Lombardi R, Porretta-Serapiglia C, et al. Amyotrophic lateral sclerosis causes small fiber pathology. Eur J Neurol 2016; 23(2): 416-20.

30. Hanisch F, Skudlarek A, Berndt J, Kornhuber ME. Characteristics of pain in amyotrophic lateral sclerosis. Brain Behav 2015; 5(3): e00296.

31. Pizzimenti A, Aragona M, Onesti E, Inghilleri M. Depression, pain and quality of life in patients with amyotrophic lateral sclerosis: a cross-sectional study. Functional neurology 2013; 28(2): 115-9.

32. Jensen MP, Abresch RT, Carter GT, McDonald CM. Chronic pain in persons with neuromuscular disease. Archives of physical medicine and rehabilitation 2005; 86(6): 1155-63.

33. Abe $\mathrm{Y}$, Miyashita $\mathrm{M}$, Ito $\mathrm{N}$, et al. Attitude of outpatients with neuromuscular diseases in Japan to pain and use of analgesics. J Neurol Sci 2008; 267(1-2): 22-7.

34. Rooney J, Byrne $\mathrm{S}$, Heverin $\mathrm{M}$, et al. Survival analysis of irish amyotrophic lateral sclerosis patients diagnosed from 1995-2010. PLoS One 2013; 8(9): e74733.

35. Kuffner R, Zach N, Norel R, et al. Crowdsourced analysis of clinical trial data to predict amyotrophic lateral sclerosis progression. Nature biotechnology 2015; 33(1): 51-7.

36. Hecht M, Hillemacher T, Grasel E, et al. Subjective experience and coping in ALS. Amyotroph Lateral Scler Other Motor Neuron Disord 2002; 3(4): 225-31.

37. Stephens HE, Young J, Felgoise SH, Simmons Z. A Qualitative Study of Multidisciplinary ALS Clinic Use in the United States. Amyotroph Lateral Scler Frontotemporal Degener 2015; 17(1-2): 55-61.

38. Lauria G, Faber CG, Merkies IS, Waxman SG. Diagnosis of neuropathic pain: challenges and possibilities. Expert opinion on medical diagnostics 2012; 6(2): 89-93.

39. Tracey I, Mantyh PW. The cerebral signature for pain perception and its modulation. Neuron 2007; 55(3): 377-91.

40. Moisset X, Cornut-Chauvinc C, Clavelou P, Pereira B, Dallel R, Guy N. Is there pain with neuropathic characteristics in patients with amyotrophic lateral sclerosis? A cross-sectional study. Palliat Med 2016; 30(5): 486-94.

41. Caress JB, Ciarlone SL, Sullivan EA, Griffin LP, Cartwright MS. Natural history of muscle cramps in amyotrophic lateral sclerosis. Muscle Nerve 2016; 53(4): 513-7.

42. Miller TM, Layzer RB. Muscle cramps. Muscle Nerve 2005; 32(4): 431-42.

43. Yosipovitch G, Bernhard JD. Clinical practice. Chronic pruritus. N Engl J Med 2013; 368(17): 1625-34.

44. Misery L, Brenaut E, Le Garrec R, et al. Neuropathic pruritus. Nat Rev Neurol 2014; 10(7): 408-16.

45. Reich A, Stander S, Szepietowski JC. Drug-induced pruritus: a review. Acta Derm Venereol 2009; 89(3): 236-44. 
46. Ho DT, Ruthazer R, Russell JA. Shoulder pain in amyotrophic lateral sclerosis. J Clin Neuromuscul Dis 2011; 13(1): 53-5.

47. Hirano YM, Yamazaki Y, Shimizu J, Togari T, Bryce TJ. Ventilator dependence and expressions of need: a study of patients with amyotrophic lateral sclerosis in Japan. Soc Sci Med 2006; 62(6): 1403-13.

48. Dangers L, Laviolette $\mathrm{L}$, Georges $\mathrm{M}$, et al. Relieving dyspnoea by non-invasive ventilation decreases pain thresholds in amyotrophic lateral sclerosis. Thorax 2016.

49. Bouvier $G$, Laviolette L, Kindler F, et al. Dyspnea-pain counterirritation induced by inspiratory threshold loading: a laser-evoked potentials study. J Appl Physiol (1985) 2012; 112(7): 1166-73.

50. Morelot-Panzini C, Demoule A, Straus C, et al. Dyspnea as a noxious sensation: inspiratory threshold loading may trigger diffuse noxious inhibitory controls in humans. J Neurophysiol 2007; 97(2): 1396-404.

51. Newrick PG, Langton-Hewer R. Pain in motor neuron disease. J Neurol Neurosurg Psychiatry 1985; 48(8): 838-40.

52. de Carvalho $M$, Swash M. Cramps, muscle pain, and fasciculations: not always benign? Neurology 2004; 63(4): 721-3.

53. D"Ovidio F, d"Errico A, Farina E, Calvo A, Costa G, Chio A. Amyotrophic Lateral Sclerosis Incidence and Previous Prescriptions of Drugs for the Nervous System. Neuroepidemiology 2016; 47(1): 59-66.

54. Adelman EE, Albert SM, Rabkin JG, Del Bene ML, Tider T, O'Sullivan I. Disparities in perceptions of distress and burden in ALS patients and family caregivers. Neurology 2004; 62(10): 1766-70.

55. Goy ER, Carter J, Ganzini L. Neurologic disease at the end of life: caregiver descriptions of Parkinson disease and amyotrophic lateral sclerosis. J Palliat Med 2008; 11(4): 548-54.

56. Oliver $\mathrm{D}$. The quality of care and symptom control--the effects on the terminal phase of ALS/MND. J Neurol Sci 1996; 139 Suppl: 134-6.

57. Cousins R, Ando H, Thornton E, Chakrabarti B, Angus R, Young C. Determinants of accepting noninvasive ventilation treatment in motor neurone disease: a quantitative analysis at point of need. Health Psychol Behav Med 2013; 1(1): 47-58.

58. Veronese S, Valle A, Chio A, Calvo A, Oliver D. The last months of life of people with amyotrophic lateral sclerosis in mechanical invasive ventilation: a qualitative study. Amyotroph Lateral Scler Frontotemporal Degener 2014; 15(7-8): 499-504.

59. Ganzini L, Silveira MJ, Johnston WS. Predictors and correlates of interest in assisted suicide in the final month of life among ALS patients in Oregon and Washington. Journal of pain and symptom management 2002; 24(3): 312-7.

60. Maessen M, Veldink JH, van den Berg LH, Schouten HJ, van der Wal G, Onwuteaka-Philipsen BD. Requests for euthanasia: origin of suffering in ALS, heart failure, and cancer patients. J Neurol 2010; 257(7): 1192-8.

61. Atassi N, Cook A, Pineda CM, Yerramilli-Rao P, Pulley D, Cudkowicz M. Depression in amyotrophic lateral sclerosis. Amyotroph Lateral Scler 2011; 12(2): 109-12.

62. Stephens HE, Lehman E, Raheja D, Yang C, Walsh S, Simmons Z. The role of mental health and selfefficacy in the pain experience of patients with amyotrophic lateral sclerosis. Amyotroph Lateral Scler Frontotemporal Degener 2016: 1-7.

63. Lepine JP, Briley M. The epidemiology of pain in depression. Hum Psychopharmacol 2004; 19 Suppl 1: S3-7.

64. Jain R. The epidemiology and recognition of pain and physical symptoms in depression. J Clin Psychiatry 2009; 70(3): e04.

65. Poole H, White S, Blake C, Murphy P, Bramwell R. Depression in chronic pain patients: prevalence and measurement. Pain Pract 2009; 9(3): 173-80.

66. Baquero M, Martin N. Depressive symptoms in neurodegenerative diseases. World J Clin Cases 2015; 3(8): 682-93.

67. Thakore NJ, Pioro EP. Depression in ALS in a large self-reporting cohort. Neurology 2016.

68. Phukan J, Elamin M, Bede $\mathrm{P}$, et al. The syndrome of cognitive impairment in amyotrophic lateral sclerosis: a population-based study. J Neurol Neurosurg Psychiatry 2012; 83(1): 102-8.

69. Fletcher PD, Downey LE, Golden HL, et al. Pain and temperature processing in dementia: a clinical and neuroanatomical analysis. Brain 2015; 138(Pt 11): 3360-72. 
70. Treede RD, Jensen TS, Campbell JN, et al. Neuropathic pain: redefinition and a grading system for clinical and research purposes. Neurology 2008; 70(18): 1630-5.

71. Smart KM, Blake C, Staines A, Doody C. Clinical indicators of 'nociceptive', 'peripheral neuropathic' and 'central' mechanisms of musculoskeletal pain. A Delphi survey of expert clinicians. Manual therapy 2010; 15(1): 80-7.

72. Woolf CJ. Central sensitization: implications for the diagnosis and treatment of pain. Pain 2011; 152(3 Suppl): S2-15.

73. Meyer RA, Campbell IT, Raja SN. Peripheral neural mechanisms of nociception. In: Wall PD, Melzack R, eds. Textbook of Pain. Edinburgh: Churchill Livingstone.; 1995: 13-44.

74. Lauria G, Devigili G. Skin biopsy as a diagnostic tool in peripheral neuropathy. Nat Clin Pract Neurol 2007; 3(10): 546-57.

75. Hammad M, Silva A, Glass J, Sladky JT, Benatar M. Clinical, electrophysiologic, and pathologic evidence for sensory abnormalities in ALS. Neurology 2007; 69(24): 2236-42.

76. Weis J, Katona I, Muller-Newen G, et al. Small-fiber neuropathy in patients with ALS. Neurology 2011; 76(23): 2024-9.

77. Isak B, Tankisi H, Johnsen B, et al. Involvement of distal sensory nerves in amyotrophic lateral sclerosis. Muscle Nerve 2016.

78. Attal N, Cruccu G, Baron R, et al. EFNS guidelines on the pharmacological treatment of neuropathic pain: 2010 revision. Eur $J$ Neurol 2010; 17(9): 1113-e88.

79. Pagnini F, Lunetta C, Banfi P, et al. Pain in Amyotrophic Lateral Sclerosis: a psychological perspective. Neurol Sci 2012; 33(5): 1193-6.

80. Nijs J, Torres-Cueco R, van Wilgen CP, et al. Applying modern pain neuroscience in clinical practice: criteria for the classification of central sensitization pain. Pain Physician 2014; 17(5): 447-57.

81. Nijs J, Apeldoorn A, Hallegraeff $\mathrm{H}$, et al. Low back pain: guidelines for the clinical classification of predominant neuropathic, nociceptive, or central sensitization pain. Pain Physician 2015; 18(3): E333-46.

82. Ziegler EA, Magerl W, Meyer RA, Treede RD. Secondary hyperalgesia to punctate mechanical stimuli. Central sensitization to A-fibre nociceptor input. Brain 1999; 122 ( Pt 12): 2245-57.

83. Woolf CJ. Evidence for a central component of post-injury pain hypersensitivity. Nature 1983; 306(5944): 686-8.

84. Agosta F, Ferraro PM, Riva N, et al. Structural brain correlates of cognitive and behavioral impairment in MND. Hum Brain Mapp 2016.

85. Chio A, Pagani M, Agosta F, Calvo A, Cistaro A, Filippi M. Neuroimaging in amyotrophic lateral sclerosis: insights into structural and functional changes. Lancet Neurol 2014; 13(12): 1228-40.

86. Kukkar A, Bali A, Singh N, Jaggi AS. Implications and mechanism of action of gabapentin in neuropathic pain. Arch Pharm Res 2013; 36(3): 237-51.

87. Verma V, Singh N, Singh Jaggi A. Pregabalin in neuropathic pain: evidences and possible mechanisms. Curr Neuropharmacol 2014; 12(1): 44-56.

88. El-Tawil S, Al Musa T, Valli H, Lunn MP, El-Tawil T, Weber M. Quinine for muscle cramps. Cochrane Database Syst Rev 2010; (12): CD005044.

89. Baldinger R, Katzberg HD, Weber M. Treatment for cramps in amyotrophic lateral sclerosis/motor neuron disease. Cochrane Database Syst Rev 2012; (4): CD004157.

90. Miller RG, Moore DH, 2nd, Gelinas DF, et al. Phase III randomized trial of gabapentin in patients with amyotrophic lateral sclerosis. Neurology 2001; 56(7): 843-8.

91. Weiss MD, Macklin EA, Simmons Z, et al. A randomized trial of mexiletine in ALS: Safety and effects on muscle cramps and progression. Neurology 2016; 86(16): 1474-81.

92. Weber M, Goldman B, Truniger S. Tetrahydrocannabinol (THC) for cramps in amyotrophic lateral sclerosis: a randomised, double-blind crossover trial. J Neurol Neurosurg Psychiatry 2010; 81(10): 1135-40.

93. Bedlack RS, Pastula DM, Hawes J, Heydt D. Open-label pilot trial of levetiracetam for cramps and spasticity in patients with motor neuron disease. Amyotroph Lateral Scler 2009; 10(4): 210-5.

94. McClelland S, 3rd, Bethoux FA, Boulis NM, et al. Intrathecal baclofen for spasticity-related pain in amyotrophic lateral sclerosis: efficacy and factors associated with pain relief. Muscle Nerve 2008; 37(3): 396-8. 
95. Chio A, Silani V, Italian ALSSG. Amyotrophic lateral sclerosis care in Italy: a nationwide study in neurological centers. J Neurol Sci 2001; 191(1-2): 145-50.

96. O'Brien T, Kelly M, Saunders C. Motor neurone disease: a hospice perspective. BMJ 1992; 304(6825): 471-3.

97. Amtmann D, Weydt P, Johnson KL, Jensen MP, Carter GT. Survey of cannabis use in patients with amyotrophic lateral sclerosis. The American journal of hospice \& palliative care 2004; 21(2): 95-104.

98. Green S, Buchbinder R, Hetrick S. Physiotherapy interventions for shoulder pain. Cochrane Database Syst Rev 2003; (2): CD004258.

99. Borasio GD, Shaw PJ, Hardiman O, et al. Standards of palliative care for patients with amyotrophic lateral sclerosis: results of a European survey. Amyotroph Lateral Scler Other Motor Neuron Disord 2001; 2(3): 159-64.

100. Carter GT, Abood ME, Aggarwal SK, Weiss MD. Cannabis and amyotrophic lateral sclerosis: hypothetical and practical applications, and a call for clinical trials. The American journal of hospice \& palliative care 2010; 27(5): 347-56.

101. Majmudar S, Wu J, Paganoni S. Rehabilitation in amyotrophic lateral sclerosis: why it matters. Muscle Nerve 2014; 50(1): 4-13.

102. Maggiani A, Tremolizzo L, Valentina AD, et al. Osteopathic Manual Treatment for Amyotrophic Lateral Sclerosis: A Feasibility Pilot Study. Open Neurol J 2016; 10: 59-66.

103. Green S, Buchbinder R, Hetrick S. Acupuncture for shoulder pain. Cochrane Database Syst Rev 2005; (2): CD005319.

104. Gay PC. Complications of noninvasive ventilation in acute care. Respir Care 2009; 54(2): 246-57; discussion 57-8.

105. Ribeiro $S$. lyengar yoga therapy as an intervention for cramp management in individuals with amyotrophic lateral sclerosis: three case reports. J Altern Complement Med 2014; 20(4): 322-6.

106. Zhang X, Hong YL, Xu DS, et al. A review of experimental research on herbal compounds in amyotrophic lateral sclerosis. Phytother Res 2014; 28(1): 9-21.

107. Pan W, Chen X, Bao J, et al. The use of integrative therapies in patients with amyotrophic lateral sclerosis in shanghai, china. Evid Based Complement Alternat Med 2013; 2013: 613596.

108. Blatzheim K. Interdisciplinary palliative care, including massage, in treatment of amyotrophic lateral sclerosis. J Bodyw Mov Ther 2009; 13(4): 328-35.

109. Drory VE, Goltsman E, Reznik JG, Mosek A, Korczyn AD. The value of muscle exercise in patients with amyotrophic lateral sclerosis. J Neurol Sci 2001; 191(1-2): 133-7.

110. Elliott SA, Brown JS. What are we doing to waiting list controls? Behav Res Ther 2002; 40(9): 1047-

52.

111. Martinez-Velilla N, Cadore L, Casas-Herrero A, Idoate-Saralegui F, Izquierdo M. Physical Activity and Early Rehabilitation in Hospitalized Elderly Medical Patients: Systematic Review of Randomized Clinical Trials. J Nutr Health Aging 2016; 20(7): 738-51. 


\section{Panel 1: Case study}

A 47-year-old man reported painful cramps in the last 2 years, involving lower limbs, feet and abdomen. The cramps were more frequent during activity, forcing the subject to interrupt the movement, and when falling asleep. The cramps had been unsuccessfully treated by patient's general practitioner with potassium and magnesium supplements, and by muscle relaxing massages. Two months before the neurological consultation, the patients started feeling weakness and mild hypotrophy in the calves and anterolateral aspect of the legs bilaterally. The cramps were getting increasingly severe, and sometimes appeared also at rest. The neurological examination found diffuse deep tendon hyperreflexia, positive Babinski and Hoffmann signs and diffuse fasciculations. Needle electromyography showed diffuse spontaneous activity and chronic neurogenic changes in lower limbs. Brain and spinal cord MRI were normal. Creatine kinase was mildly elevated. A diagnosis of ALS was done and the patients started riluzole at the dose of 100 $\mathrm{mg}$ daily. After having excluded the presence of disturbances of the cardiac rhythm, the patient was treated with quinine sulphate $250 \mathrm{mg}$ at bedtime that provided a substantial reduction of cramp frequency and intensity. 


\section{Panel 2: Case study}

A 57-year-old woman was referred for a 3-year history started with pain in the left sole with proximal progression to both the lower limbs followed by impaired gait with need of assistance for climbing the stairs, lower limb weakness and behavioural changes with irritability and emotional lability. She had fallen five times in the last year. Family history was negative and she did not report known consanguinity up to the grandparents. The neurological examination showed paraparesis and moderate spasticity of the left lower limb, weakness of the distal muscle of the upper limbs and of both proximal and distal muscle of the lower limbs, diffuse deep tendon hyperreflexia, positive Babinski and Hoffmann signs, reduced pinprick sensation with a stocking distribution and absent vibratory sensation at the first metatarsal joint using the $64 \mathrm{~Hz}$ RydelSeiffer tuning fork. Needle electromyography showed diffuse spontaneous activity and chronic neurogenic changes. Nerve conduction studies showed reduced amplitude of compound muscle action potential amplitudes with normal conduction velocities, whereas sensory nerve action potentials and conduction velocities were normal. Somatosensory evoked potentials recorded by stimulating the upper limbs were normal and showed increased central conduction latency by stimulating the lower limbs. Motor evoked potentials were normal recording from the upper limbs and showed increased central conduction latency from the lower limbs. Skin biopsy showed reduced intraepidermal nerve fibre density compared to age and sex-adjusted normative values. $\mathrm{A}$ diagnosis of neuropathic pain was therefore considered. Brain and spinal cord magnetic resonance imaging studies were normal. The genetic study revealed the p.N65S mutation in SOD1 gene. ALS was diagnosed and riluzole $100 \mathrm{mg}$ daily started. She was taking pregabalin $150 \mathrm{mg}$ and tramadol $50 \mathrm{mg}$ daily. At follow-up visits, besides the progressive motor impairment, the patients complained of persistent and severe pain in the lower limbs scored 7 at the visual analogue scale. Pregabalin and tramadol were suspended and amitriptyline was progressively increased up to 50 mg daily, which provided $50 \%$ of pain intensity reduction that the patient reported as a satisfactory relief. 


\section{Panel 3: Case study}

A 56-years-old came to our attention after a 3-year history of ALS. He presented a classic phenotype with moderate dysarthria, swallowing problems requiring soft diet, paresis of the 4 limbs with spasticity in the lower limbs and no symptom or sign of respiratory failure. Transfers required some aid. Gait was possible with a walker but for short distances (few metres). His major complaint was disturbed sleep with frequent arousals due to diffuse pain, in particular neck, shoulders and back. The clinical characteristics of pain in this patients pointed toward a potential diagnosis of nociceptive pain. The only medication was riluzole; an attempt with the hypnotic medication zolpidem had been interrupted because of no efficacy. He followed physical therapy only occasionally. At the visit, both shoulders had a limited excursion, and passive movements elicited acute pain; lower limbs showed marked spasticity. The patient was addressed to daily sessions of physiotherapy with active/passive range of motion and stretching exercises; the caregiver was trained in transfer techniques. Baclofen at increasing dosage demonstrated efficacy in reducing spasticity and enabled the patients to maintain the postures in bed for longer time. The prescription of a mattress of viscoelastic foam also improved the quality of sleep. The adjunct of tizanidine was aborted for excessive daily somnolence even at low dose. An attempt with cannabinoids (Sative ${ }^{\circledR}$ oromucosal spray, $3 \mathrm{ml} /$ day, corresponding to delta-9tertahydrocannabinol $81 \mathrm{mg}$ plus cannabidiol $75 \mathrm{mg}$ ) was not tolerated for the occurrence of dizziness and confusion. A combination of acetaminophen plus codeine provided a satisfactory pain relief. 


\section{Figure legend}

Graphic description of types of pain in ALS. All reported types of pain are secondary in nature (mainly nociceptive), with the exception of neuropathic pain. Green shading=primary pain. Blue shading=secondary (mainly nociceptive) pain. 